\title{
Assessment of the Impact of Different Diagnostic Definitions on REM-related Obstructive Sleep Apnea: Board versus Restricted?
}

\section{Genel ve Sınırı Tanı Kriterlerinin REM Ilișskili Obstrüktif Uyku Apne Sendromu Üzerine Etkisinin Incelenmesi: Genel ya da Sınırlı?}

\author{
(1) Burcu Oktay Arslan, (• Özlem Yalnız, • Zeynep Zeren Uçar Hoşgör \\ University of Health Sciences Turkey, Dr. Suat Seren Chest Disease and Chest Surgery Training and Research Hospital, Sleep Disorders Center, Izmir, Turkey
}

\begin{abstract}
Objective: To evaluate the differences in demographic and polysomnographic (PSG) features between the board and restricted definitions of rapid eye movement (REM)-related obstructive sleep apnea (OSA), and whether different diagnostic criteria lead to different clinical classifications and treatment approaches.

Materials and Methods: A total of 1096 patient files were screened for REM-related OSA. Patients with REM-related OSA were included in the study and classified into two groups according to the board and restricted definition of REM-related OSA. Demographic and PSG features and treatment approaches were compared between both groups.

Results: This study Included a total of 154 patients: 33 (21.4\%) were classified as restricted REM-related and 121 (78.6\%) as board REMrelated OSA. There were no differences between the two groups in terms of age $(p=0.061)$, sex $(p=0.274)$, Body Mass index $(p=0.055)$, and co-morbidities $(p=0.299)$. Significant differences were observed between the groups with regard to Epworth Sleepiness scale $(p=0.033)$. The total Apne-hipopne index (AHI), AHIREM, and AHINREM in the board REM-related OSA group were significantly higher than those in the restricted REM-related OSA group $(p<0.001)$. Treatment with only lifestyle interventions was recommended to fifty-one (35.1\%) patients, whereas positive airway passage therapy was recommended to 100 (64.9\%) patients. Forty-one $(26.6 \%)$ patients refused PAP titration. Lifestyle interventions only were recommended more commonly to patients with restricted REM-related OSA than to those with board REMrelated OSA $(p=0.004)$.

Conclusion: The restricted definition of REM-related OSA yields milder but sleepy patients compared with the board definition. Particular attention should be given to sleepy patients with milder REM-related OSA with regard to the treatment options. Not only lifestyle interventions, but also PAP therapy should be considered in the treatment of patients who are sleepier.
\end{abstract}

Keywords: Sleep disordered breathing, REM-related OSA, diagnosis
Öz

Amaç: Sınırlı ve genel tanı kriterine göre hızlı göz hareketi [rapid eye movement (REM)]-ilişkili obstrüktif uyku apnesi (OSA) tanısı alan hasta gruplarının demografik ve polisomonografik (PSG) parametreler açısından karşılaştırılması ve farklı tanı kriterlerinin farklı sınıflama ve tedavi yaklaşımlarına neden olup olmadığının değerlendirilmesidir.

Gereç ve Yöntem: Hastanemiz uyku laboratuvarında 1 yıl içerisinde yapılan 1096 polisomografi tetkiki retrospektif olarak tarandı. REM-ilişkili OSA tanısı alan hastalar çalışmaya dahil edildi. Hastalar genel ve sınırlı tanı kriterlerine göre 2 gruba ayrıldı. Gruplar demografik özellikler, PSG bulgular ve tedavi yaklaşımları açısından karşılaştıııldı.

Bulgular: REM-ilişkili OSA tanısı alan 154 hasta çalışmaya dahil edildi. Yüz yirmi bir $(\% 78,6)$ hasta genel kritere göre, $33(\% 21,4)$ hasta sınırlı kritere göre REM-ilişkili OSA tanısı aldı. Gruplar arasında yaş $(p=0,061)$, cinsiyet $(p=0,274)$, vücut kitle indeksi $(p=0,055)$, ve ko-morbiditeler $(p=0,299)$ açısından istatistiksel olarak anlamlı farklılık izlenmedi $(p=0,299)$. Epworth Uykuluk skalası açısından gruplar arasındaki fark istatistiksel olarak anlamlı idi $(p=0,033)$. Genel kritere göre REM-ilişkili OSA tanısı alan grupta Apne-hipopne indeksi (AHI), AHIREM, ve AHINREM, sınılı kriterlere göre REM-ilişkili OSA tanısı alan gruba kıyasla daha yüksek tespit edildi $(p<0,001)$. Tedavi yaklaşımları değerlendirildiğinde 54 $(\% 35,1)$ hastaya yalnızca yaşam tarzı değişiklikleri önerilirken, 100 hastaya $(\% 64,9)$ pozitif havayolu basıncı (PAP) tedavisi önerildi. Kırk bir $(\% 26,6)$ hasta PAP tedavisi kabul etmedi. Sınırlı kritere göre REMilişkili OSA tanısı alan hasta grubunda, genel kritere göre tanı alanlara oranla daha fazla yalnızca yaşam tarzı değişiklikleri önerildiği görüldü $(\mathrm{p}=0,004)$.

Sonuç: REM-ilişkili OSA tanısında sınırı tanı kriteri ile genel tanı kriteri karşılaştııılığında, sınırlı kriterlerin daha hafif şiddetli ancak daha uykulu REM-ilişkili OSA hastalarını ortaya çıkardığı görülmüştür. Hafif ancak uykulu olan REM-ilişkili OSA hastaları tedavi yaklaşımları açısından dikkatle değerlendirilmelidir. Yalnızca yaşam tarzı değişiklikleri değil, PAP tedavisi de hafif ancak uykulu REM-ilişkili OSA hastalarının tedavisinde göz önünde bulundurulmalıdır.

Anahtar Kelimeler: Uykuda solunum bozuklukları, REM-ilişkili OSA, tanı kriterleri

Address for Correspondence/Yazışma Adresi: Burcu Oktay Arslan MD, University of Health Sciences Turkey, Dr. Suat Seren Chest Disease and Chest Surgery Training and Research Hospital, Sleep Disorders Center, İzmir, Turkey Phone: +90 5056687243 E-mail: dr.arslanburcu@gmail.com ORCID-ID: orcid.org/0000-0002-4865-8982 Received/Geliş Tarihi: 29.01.2020 Accepted/Kabul Tarihi: 17.05.2020 


\section{Introduction}

Obstructive sleep apnea(OSA) is a common disorder characterized by repetitive upper airway collapse during sleep, resulting intermittent hypoxemia, arousal from sleep, and changes in blood pressure and heart rate (1). Several factors including upper airway anatomy, arousal threshold, inherent stability of respiratory control system, and the ability of upper airway dilator muscles to respond to the pharyngeal collapse during sleep determine the pathogenesis of OSA (2). OSA represents a heterogeneous group of patients with a multifactorial etiology comprising anatomic and physiologic factors, and variable degrees of positional and state dependencies (3). Among OSA phenotypes, rapid eye movement (REM)-related OSA has been drawing attention in terms of its relationship with cardiovascular diseases and hypertension $(4,5)$. REM-related OSA refers to the occurrence of respiratory events, predominantly or exclusively during REM sleep. REM sleep is associated with irregular respiration, decreased tidal volume and minute ventilation, and reduced responsiveness to respiratory modulation (6). The severity of OSA typically worsens during REM sleep with more common and greater length of apneas, greater hypoxemia than during non-rapid eye movement (NREM) sleep (7). The estimated prevalence rate for REM-related OSA in clinical studies ranges from $10 \%$ to $36 \%$, depending on the sample characteristics and the definition of REM-related OSA (8).

There is still no universally accepted definition for REM-related OSA. The most common criteria used to describe REM-related OSA is based on the ratio of the Apnea-hypopnea index (AHI) during REM and NREM sleep $\left(A \mathrm{AI}_{\mathrm{REM}} / \mathrm{AHI}_{\mathrm{NREM}}\right)$. However, this definition, which is criticized being board, will undoubtedly include more patients under the category of REM-related OSA (9). Indeed, there may be a substantial disease during NREM sleep. Additionally, the board definition has no criteria for the REM sleep duration. When the $\mathrm{AHI}$ is calculated, although the number of respiratory evets is low, a high index can be obtained when the REM sleep duration is too short. Therefore, having a minimal requirement of REM sleep duration is critical to evaluate the presence of REM-related OSA (10). Several definitions have been proposed to identify REM-related OSA because of the previously mentioned reasons (11). Mokhlesi and Punjabi (10) proposed the following restricted criteria for diagnosing REM-related OSA: $\mathrm{AHI}_{\mathrm{REM}} \geq 5$ and $\mathrm{AHI}_{\mathrm{NREM}}<5$, with a total REM sleep duration of at least 30 minutes.

The purpose of this study was to evaluate the differences of demographic and polysomnographic (PSG) features between board and restricted definitions of REM-related OSA, and to try to determine whether different diagnostic criteria lead to different clinical classifications and treatment approaches.

\section{Materials and Methods}

\section{Patients}

This study was a retrospective analysis of patients who had in-lab PSG examinations between January 2017 and January 2018 at the sleep center of University of Health Sciences Turkey, Dr. Suat Seren Training and Research Hospital. One thousand ninety-six patients underwent PSG examinations within this period. PSG examinations of the 1.096 patients were evaluated retrospectively. The exclusion criteria were as follows: age $<18$ years, PSG examination with a positive airway pressure (PAP) device, PSG examination continued with multiple sleep latency test, PSG examination with oxygen, diagnosis of other sleep disorders (e.g. central sleep apnea, sleep related movement disorders) sleep efficacy $<60 \%, \mathrm{AHI}<5$ events/hour, and $\mathrm{AHI}_{\text {REM }} / \mathrm{AHI}_{\text {NREM }} \leq 2$. In total, 154 patients with $\mathrm{AHI} \geq 5$ events/ hour and $\mathrm{AHI}_{\mathrm{REM}} / \mathrm{AHI} \mathrm{NREM}_{\mathrm{N}}>2$ were included in the study. Figure 1 demonstrates the flow diagram and details of the excluded case numbers.

Patients were classified into two groups according to the board and restricted definition of REM sleep. Board REM-related OSA is defined as $A H I_{\text {REM }} / A H I_{\text {NREM }}$ at least 2. Restricted REM-related OSA is defined as $A \mathrm{HI}_{\mathrm{REM}} \geq 5$ and $A \mathrm{AI}_{\text {NREM }}<5$, with a total REM sleep duration of at least 30 minutes. Demographic information [age, sex, Body Mass index (BMI), smoking habits], Epworth Sleepiness score (ESS), and the comorbid diseases of the patients were obtained. We used valid Turkish version of the ESS (12). Treatment modalities administered to the patients were also recorded. Treatment methods were classified into three groups as follows: the first group included patients who were offered only lifestyle interventions (weight loss, exercise, alcohol avoidance, sleep position, concomitant medications), the second group comprised patients who had PAP therapy, and the third group constituted patients who rejected PAP titration. In our clinic, patients who are recommended PAP

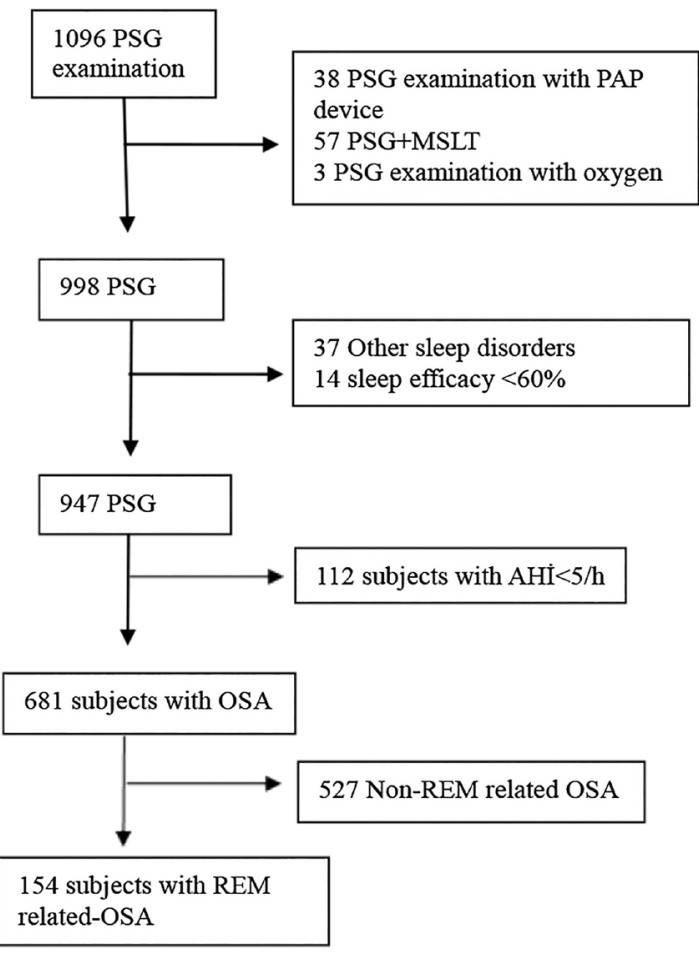

Figure 1. Flow diagram

PSG: Polysomnography, PAP: Positive airway pressure, MSLT: Multiple sleep latency test, AHI: Apnea-hypopnea index, REM: Rapid eye movement, OSA: Obstructive sleep apnea 
therapy are firstly given training about PAP devices and then a mask test is performed. The third group included patients who did not accept PAP titration after having training and mask testing.

\section{Polysomnography}

The diagnosis of OSA was made using in-lab PSG examinations. Electroencephalography, electro-oculography, and electromyography of the chin and leg (anterior tibialis), electrocardiography, oxygen saturation (from the fingertips), respiratory effort (thoracic, abdominal), and air flow (nasal pressure transducer and oronasal thermistor), body position, and tracheal sound was recorded using a comet grass telefactor, version 4.5.3. PSG recordings were analyzed by a physician experienced in sleep disorders using the TWin ${ }^{\circledR}$ EEG/PSG software. Scoring of sleep and respiratory events was performed according to the criteria of the American Academy of Sleep Medicine manual, version 2.3 (13). The severity of OSA was categorized as follows: mild ( $5 \leq \mathrm{AHI}<15$ events/h), moderate (15 $\leq \mathrm{AHI}<30$ events/h), and severe (AHI $\geq 30$ events/h).

\section{Statistical Analysis}

The data were analyzed using the IBM-SPSS 25.0 package. Quantitative data are reported as mean \pm standard deviation or as median with minimum-maximum values while qualitative data are reported as observed frequencies and percentages. Shapiro-Wilk test was used to check normality and according to the results parametric or non-parametric suitable statistical tests were performed. An independent samples t-test or nonparametric alternative of it Mann-Whitney $U$ test was used to compare two groups for a quantitative variable. A chi-square test applied to assess association between qualitative variables. The level of significance was set at 0.05 .

\section{Compliance with Ethical Standards}

Ethical committee permission: The study was approved by the local research ethics committee (University of Health Sciences Turkey. Dr. Suat Seren Chest Disease and Chest Surgery, Training and Research Hospital date: 22.02.2019, number: 3). Research involving human participants and/or animals: All procedures performed in studies involving human participants were in accordance with the ethical standards of the institutional and/or national research committee and with the 1964 Helsinki declaration (as revised in Edinburgh 2013) and its later amendments or comparable ethical standards. Informed consent was obtained from all individual participants included in the study.

\section{Results}

In this study, PSG examinations of 1096 patients were screened for REM-related OSA and a total of 154 patients were included in the study. Of the subjects with $\mathrm{AHI} \geq 5$ (681 patients), 154 (22.6\%) patients had an $\mathrm{AHI}_{\text {REM }} / \mathrm{AHI}_{\text {NREM }} \geq 2$. The study group was aged $51 \pm 11$ years with a BMl of $33.08 \pm 5.85 \mathrm{~kg} / \mathrm{m}^{2}$. Fiftyone percent of the participants were male. The ESS score was $8.61 \pm 5.60$. Hypertension and diabetes mellitus were the most common comorbid conditions in both groups. The baseline demographic characteristics of the patients are given in Table
1. According to the PSG results, 89 (57.8\%) patients had mild OSA, 56 (36.4\%) patients had moderate OSA, and 9 (5.8\%) patients had severe OSA.

Among the 154 patients, 33 (21.4\%) patients were classified as restricted REM-related OSA according to the restricted REMrelated OSA definition. One hundred twenty-one (17.7\%) patients were included in the board, but not in the restricted definition and classified as board REM-related OSA. There were no differences between the two groups with regard to age $(p=0.061)$, sex $(p=0.274), B M I(p=0.055)$, STOP-Bang score $(p=0.517)$, and history of hypertension $(p=0.528)$ and diabetes mellitus $(p=0.999)$. However, there was a significant difference regarding ESS between the restricted REM-related OSA and board REM-related OSA groups $(p=0.033)$ (Table 2). The sleep study data of the restricted REM-related OSA and board REM-related OSA groups are presented in Table 3. Regarding sleep stages, there was a significant difference between the two groups. The percentages of stage NREM-2 was longer in board REM-related OSA than in restricted REM-related OSA $(p=0.001)$. Both percentages and the duration of REM sleep, and percentages of stage NREM-3 were longer in patients with restricted REM-related OSA compared with those with board REM-related OSA ( $p=0.001, p=0.006, p=0.013$, respectively). Latency to REM sleep was shorter in the restricted REM-related OSA group compared with the board REM-related OSA group $(p=0.043)$. The mean total $A H I, A H I_{R E M}, A H I_{N R E M}$ and supine $\mathrm{AHI}$ in the board REM-related OSA group were significantly higher compared with the restricted REM-related OSA group $(p<0.001, p<0.001, p<0.001, p<0.001$ respectively $)$. In the board REM-related OSA group, the Oxygen Desaturation index (ODI) and arousal index were higher than in the restricted-REM related OSA group $(p<0.001, p=0.004$, respectively). There was also a significant difference between the groups regarding minimum oxygen saturation $(p=0.004)$.

\begin{tabular}{|l|l|}
\hline \multicolumn{2}{|l|}{ Table 1. Demographic data of the study population $(\mathbf{n}=\mathbf{1 5 4})$} \\
\hline $\begin{array}{l}\text { Age, year } \\
\text { Male gender, } \mathrm{n}(\%)\end{array}$ & $\begin{array}{l}51 \pm 11 \\
78(50.6)\end{array}$ \\
\hline BMl, $\mathrm{kg} / \mathrm{m}^{2}$ & $33.08 \pm 5.85$ \\
\hline Neck circumference, $\mathrm{cm}$ & $40.9 \pm 3.49$ \\
\hline Smoker, $\mathrm{n}(\%)$ & $59(38.3)$ \\
\hline Snoring, $\mathrm{n}(\%)$ & $149(96.8)$ \\
\hline Witnessed apnea, $\mathrm{n}(\%)$ & $125(81.2)$ \\
\hline Daytime sleepiness, $\mathrm{n}(\%)$ & $136(88.3)$ \\
\hline Hypertension, $\mathrm{n}(\%)$ & $61(39.6)$ \\
\hline Diabetes mellitus, $\mathrm{n}(\%)$ & $35(22.7)$ \\
\hline COPD, $\mathrm{n}(\%)$ & $14(9.1)$ \\
\hline Asthma, $\mathrm{n}(\%)$ & $17(11)$ \\
\hline Hypotroidism, $\mathrm{n}(\%)$ & $13(8.4)$ \\
\hline Arrythmia, $\mathrm{n}(\%)$ & $10(6.5)$ \\
\hline CAD, $\mathrm{n}(\%)$ & $9(5.8)$ \\
\hline ESS & $8.61 \pm 5.60$ \\
\hline $\begin{array}{l}\text { BMl: Body mass index, COPD: Chronic obstructive pulmonary disease, CAD: } \\
\text { Coronary artery disease, ESS: Epworth Sleepiness score, data is depicted as } \\
\text { mean } \pm \text { standard deviation or number (percentage) }\end{array}$ \\
\hline
\end{tabular}


Of the study group, 54 (35.1\%) patients were recommended lifestyle interventions only as treatment. PAP therapy was recommended to 100 (64.9\%) patients in the study group. However, 41 (26.6\%) patients did not attempt PAP therapy as a treatment option and refused titration immediately. Fiftynine $(38.3 \%)$ patients received PAP titration. All patients were responsive to PAP therapy. The treatment methods given to the subjects are illustrated in Table 4 . In terms of lifestyle

\begin{tabular}{|c|c|c|c|}
\hline Number (\%) & $33(21.4)$ & $121(78.6)$ & \\
\hline Age, year & $47.5 \pm 11.6$ & $51.5 \pm 11.0$ & 0.061 \\
\hline $\mathrm{BMI}, \mathrm{kg} / \mathrm{m}^{2}$ & $31.1 \pm 4.0$ & $33.6 \pm 6.1$ & 0.055 \\
\hline Daytime sleepiness, n (\%) & $31(93.9)$ & $105(86.8)$ & 0.365 \\
\hline ESS & $10.5 \pm 5.8$ & $8.08 \pm 5.45$ & 0.033 \\
\hline STOP-Bang score & $4.9 \pm 1.0$ & $5.0 \pm 1.3$ & 0.517 \\
\hline Diabetes mellitus, n (\%) & $8(24.2)$ & $27(22.3)$ & 1.000 \\
\hline Hypertension, n (\%) & $11(33.3)$ & $50(41.3)$ & 0.528 \\
\hline
\end{tabular}

Table 3. Comparison of the sleep study data of the restricted rapid eye movement-related obstructive sleep apnea and board rapid eye movement-related obstructive sleep apnea groups

\begin{tabular}{|c|c|c|c|}
\hline & Restricted REM-related OSA group $(n=33)$ & Board REM-related OSA group $(n=121)$ & $\mathbf{p}$ \\
\hline TST (min) & $409.4 \pm 53.2$ & $401.9 \pm 51.1$ & 0.369 \\
\hline Sleep efficacy (\%) & $83.6 \pm 9.4$ & $82.3 \pm 8.7$ & 0.408 \\
\hline NREM 1 (\%TST) & $1.8 \pm 1.07$ & $1.7 \pm 1.10$ & 0.505 \\
\hline NREM 2 (\%TST) & $51.2 \pm 13.4$ & $60.4 \pm 14.9$ & 0.001 \\
\hline NREM3 (\% TST) & $26.6 \pm 12.4$ & $21.0 \pm 13.4$ & 0.013 \\
\hline REM (min) & $82.4 \pm 25.7$ & $67.3 \pm 31.3$ & 0.006 \\
\hline Latency to REM sleep (min) & $114.9 \pm 85.3$ & $139.68 \pm$ & 0.043 \\
\hline Supine body position (\%TST) & $43.3 \pm 25.0$ & $44.1 \pm 29.6$ & 0.883 \\
\hline $\mathrm{AHI}$ (events/h) & $8.8 \pm 5.2$ & $17.4 \pm 10.4$ & $<0.001$ \\
\hline REM AHI (events/h) & $24.7 \pm 11.0$ & $38.3 \pm 15.6$ & $<0.001$ \\
\hline Minimum $\mathrm{SpO}_{2}(\%)$ & $84.3 \pm 5.7$ & $80.4 \pm 7.6$ & 0.004 \\
\hline Average $\mathrm{SpO}_{2}(\%)$ & $94.6 \pm 1.6$ & $93.7 \pm 2.6$ & 0.105 \\
\hline Arasual index & $6.70(0.3-217.0)$ & $9.40(0.1-186.5)$ & 0.008 \\
\hline
\end{tabular}

\begin{tabular}{|l|l|l|l|}
\hline \multicolumn{2}{|l|}{ Table 4. Treatment modalities applied to the subjects } \\
\hline Treatment options & Restricted REM-related OSA group (n=33) & Board REM-related OSA group (n=121) & $\mathbf{p}$ \\
\hline Lifestyle interventions, $\mathrm{n}(\%)$ & $19(57.6)$ & $35(28.3)$ & $\mathbf{0 . 0 0 4}$ \\
\hline PAP therapy, $\mathrm{n}(\%)$ & $8(24.2)$ & $51(42.5)$ & 0.088 \\
\hline PAP titration rejection, $\mathrm{n}(\%)$ & $6(18.2)$ & $35(29.2)$ & 0.298 \\
\hline OSA: Obstructive sleep apnea, REM: Rapid eye movement, PAP: Positive airway pressure & \\
\hline
\end{tabular}


interventions as a treatment option, there was a statistically significant difference between the restricted REM-related OSA group and the board REM-related OSA group $(p=0.004)$. Regarding PAP therapy, no statistically significant differences were found between the restricted REM-related OSA group and board REM-related OSA group $(p=0.088)$. There was also no statistically significant difference regarding PAP titration rejection in both groups $(p=0.298)$. Demographic features and PSG findings were compared between the groups that accepted and rejected PAP titration. There were no statistically significant differences between the groups regarding age, sex, BMI, ESS, and co-morbidities $(p=0.326, p=0.319, p=0.240, p=0.257$, $p=0.611$, respectively). In terms of PSG findings, only average $\mathrm{SpO}_{2}$ levels during sleep were found to be lower in patients who accepted PAP titration compared with those who rejected PAP titration, but there were no significant differences in total $\mathrm{AHI}$, $\mathrm{AHI}_{\text {REM }}, \mathrm{AHI}_{\text {NREM }}$ and ODI $(\mathrm{p}=0.04, \mathrm{p}=0.393, \mathrm{p}=0.473, \mathrm{p}=0.634$, $p=0.370$, respectively). Twenty $(48.7 \%)$ of the patients who refused PAP titration were diagnosed as having mild OSA, 19 (46.3\%) as moderate, and two (4.8\%) as having severe OSA.

\section{Discussion}

This study examined the demographic and PSG characteristics of patients with REM-related OSA based on the definition that was applied for diagnosis. Our results demonstrated that the restricted definition of REM-related OSA yielded milder but sleepy patients compared with board definition of REM-related OSA. Considering the relationship between cardiovascular diseases and excessive daytime sleepiness (EDS), treatment modalities should be evaluated cautiously in this group of patients who were milder but sleepy. Of the patients who had PSG examinations in our sleep laboratory over a one-year period, 22.6\% were diagnosed as having REM-related OSA according to the board definition, and only $4.8 \%$ were diagnosed as having REM-related OSA according to the restricted definition. Previous studies demonstrated that REM-related OSA occurred more commonly in younger individuals, women, and patients with mild-to-moderate OSA (14). In our REM-related OSA population, the ratio of male to female patients was half, and the rate of mild-to-moderate OSA was $94.2 \%$. When we compared the restricted REM-related OSA group with the board REM-related OSA groups regarding baseline characteristics, a statistically significant difference was obtained in terms of ESS scores. Restricted REM-related OSA was associated with EDS using the ESS compared with board REM related OSA. In contrast to our study, Al Oweidat et al. (9) found no significant differences regarding ESS scores between patients with restricted REM-related OSA and board REM-related OSA. There are conflicting reports regarding whether REM-related OSA is associated with EDS. Some studies (15) reported that there was a significant association between REM-related OSA and daytime sleepiness, whereas other studies $(16,17)$ found no association. A recently published paper revealed that adults with OSA who experienced EDS appeared to be at far greater risk for cardiovascular diseases than those without EDS (18). The prevalence of EDS in the general population varies from $9 \%$ to $28 \%$ and has been associated with significant consequences, including increased metabolic, cardiovascular, neurologic, and psychiatric diseases and mortality (19). EDS is one of the major symptoms of OSA and $58.3 \%$ of patients with OSA referred to hospital have varying degrees of daytime sleepiness (20). Previous studies have shown that the correlation between OSA severity and ESS scores is weak or even nonexistent. The relationship between OSA and EDS seems to be influenced by various factors including intermittent hypoxia, inflammation, and genetic predisposition rather than AHI. Different phenotypes have been progressively identified in OSA and daytime sleepiness has become a primary criterion for symptom-based OSA classification (21). When the PSG findings of the restricted REM-related OSA and board REMrelated OSA groups were compared, it was revealed that the board definition was associated with more severe disease than with the restricted definition in this study. These findings are in accordance with a previous study (9).

In our study, patients with restricted REM-related OSA were sleepier although they had milder disease severity compared with those with board REM-related OSA. Considering the relation between cardiovascular diseases and EDS, particular attention should be paid to this group of patients. Using the restricted definition for the diagnosis of REM-related OSA led to exclusion of NREM disease. Thus, this only gives the opportunity of evaluating REM-related respiratory events and outcomes. It is well established that REM sleep is associated with greater sympathetic activity, lower vagal tone, and increased cardiovascular instability compared with non-REM sleep (10). In a community-based population, when overall $\mathrm{AHI}$ was replaced with NREM AHI and REM AHI, only REM AHI was significant in all models, suggesting that hypertension is mainly driven by REM OSA (4).

When the treatment methods given to the patients were evaluated, it was seen that lifestyle interventions were more commonly recommended to patients with restricted REMrelated OSA than board REM-related OSA. To our knowledge, these are no previous data evaluating the relation between REM-related OSA definitions and treatment approaches. A retrospective evaluation of our data revealed that we tended to recommend only lifestyle interventions for those with restricted REM-related OSA, and those with board REM-related OSA were more likely to receive PAP therapy. This could be because the restricted REM-related OSA group was associated with milder disease severity in our study population. Although the restricted REM-related OSA group was milder than the board REM-related OSA group, in light of the fact that the REM-related OSA group was sleepier and EDS was associated with cardiovascular diseases, this group of patients should be evaluated more carefully in terms of PAP therapy. The restricted definition of REM-related OSA revealed more REM-related and sleepier patients, which were both related with increased cardiovascular risk. Although this group of patients did not get enough attention in the board definition as mild REM-related OSA, we think it becomes more visible with the restricted criteria. However, it was proposed that the excluded patients 
with the restricted criteria were probably the ones with severe OSA (overall $\mathrm{AHI} \geq 30$ ), with a higher prevalence of hypertension (11). Although this criticism is justified, it is clear that there is no hesitation in recommending PAP therapy to patients with severe OSA (22). Additionally, only $5.8 \%$ of the patients with REM-related OSA were diagnosed as having severe OSA in this study population, which is consistent with the literature $(23,24)$. REM-related OSA still creates a difficult dilemma for physicians (25).

Another finding that needs to be discussed in our study is the high rate of patients who refused PAP titration. PAP therapy is still regarded as the most effective treatment for OSA and for reducing OSA-related symptoms and cardiovascular disease morbidity and mortality (26). Unfortunately, previous studies reported that $29 \%$ to $83 \%$ of patients are non-adherent to continuous PAP (CPAP) therapy (27). CPAP acceptance and adherence are critical issues for optimal treatment outcomes. Low CPAP acceptance and adherence is an ongoing challenge despite efforts to improve patient comfort and support (28). Some studies reported non-acceptance rates of up to $70 \%$ (29). Inconvenience, affordability issues, and poor disease awareness were the main reasons for rejection of CPAP treatment (30). Although PAP devices are paid for by the national healthcare scheme in our country, low results on PAP titration acceptance were found. Almost half of all patients with REM-related OSA who were recommended PAP therapy did not attempt PAP titration in this study. When the patient groups who accepted PAP titration and those who rejected PAP titration were compared in terms of demographic features and PSG data, no differences was observed except for average $\mathrm{SpO}_{2}$ level during sleep. Psychological traits, disposition, and the patient's perception of OSA symptoms and therapy are also important in acceptance and adherence (31). Forty-one patients who fulfilled the criteria for PAP titration immediately refused the treatment in this study. Improving disease awareness of patients with OSA who do not even want to try titration can help to change their perspective.

\section{Study Limitations}

This study has several limitations that must be addressed. First, the study sample was evaluated retrospectively. The majority of our sample had mild-to moderate OSA, which could a raise a concern for a potential bias in representing the results. The number of patients in restricted REM-related OSA group remained relatively low. The history of the hypothyroidism was recorded from the patients' files, but blood tests could not be performed to evaluate thyroid function tests. In addition, adherence to PAP device treatment could not evaluated because it was not included in the study protocol.

\section{Conclusion}

Using the restricted definition of REM-related OSA yields milder but sleepy patients compared with the board definition. Particular attention should be taken over sleepy patients with milder REM-related OSA regarding treatment options. Not only lifestyle interventions but also PAP therapy should be considered in the treatment of patients who are sleepier. The restricted definition seems to represent sleepy patients with milder REM-related OSA. Future clinical studies are required to validate this approach.

\section{Ethics}

Ethics Committee Approval: The study was approved by the local research ethics committee (Dr. Suat Seren Chest Disease and Chest Surgery, Training and Research Hospital date: 22.02.2019, number: 3).

Informed Consent: Consent form was filled out by all participants.

Peer-review: Internally peer-reviewed.

\section{Authorship Contributions}

Concept: B.O.A, Ö.Y., Design: B.O.A, Ö.Y., Z.Z.U.H., Data Collection or Processing: B.O.A, Ö.Y., Analysis or Interpretation: B.O.A, Z.Z.U.H., Literature Search: B.O.A, Ö.Y., Z.Z.U.H., Writing: B.O.A, Z.Z.U.H.

Conflict of Interest: No conflict of interest was declared by the authors.

Financial Disclosure: The authors declared that this study received no financial support.

\section{References}

1. Mesarwi OA, Sharma EV, Jun JC, Polotsky VY. Metabolic dysfunction in obstructive sleep apnea: A critical examination of underlying mechanisms. Sleep Biol Rhythms 2015;13:2-17.

2. Subramani $Y$, Singh $M$, Wong J, Kushida CA, Malhotra A, Chung F. Understanding Phenotypes of Obstructive Sleep Apnea: Applications in Anesthesia, Surgery, and Perioperative Medicine. Anesth Analg 2017; 124:179-91.

3. Peker Y, Redline S. Update in sleep medicine 2013. Am J Respir Crit Care Med 2014;189:1345-50.

4. Mokhlesi B, Finn LA, Hagen EW, Young T, Hla KM, Van Cauter E, Peppard PE. Obstructive sleep apnea during REM sleep and hypertension. results of the Wisconsin Sleep Cohort. Am J Respir Crit Care Med 2014;15:1158-67.

5. Aurora RN, Crainiceanu C, Gottlieb DJ, Kim JS, Punjabi NM. Obstructive sleep apnea during REM sleep and cardiovascular disease. Am J Respir Crit Care Med 2018;197:653-60.

6. Su CS, Liu KT, Panjapornpon K, Andrews N, Foldvary-Schaefer N. Functional outcomes in patients with REM-related obstructive sleep apnea treated with positive airway pressure therapy. J Clin Sleep Med 2012;8:243-7.

7. McSharry DG, Saboisky JP, Deyoung P, Jordan AS, Trinder J, Smales E, Hess L, Chamberlin NL, Malhotra A. Physiological Mechanisms of Upper Airway Hypotonia during REM Sleep. Sleep 2014;37:561-9.

8. Alzoubaidi M, Mokhlesi B. Obstructive sleep apnea during rapid eye movement sleep: clinical relevance and therapeutic implications. Curr Opin Pulm Med 2016;22:545-54.

9. Al Oweidat K, Alryalat SA, Al-Essa M, Obeidat N. Comparing REM-and NREM-Related Obstructive Sleep Apnea in Jordan: A Cross-Sectional Study. Can Respir J 2018;2018:9270329.

10. Mokhlesi B, Punjabi NM. "REM-related" Obstructive Sleep Apnea: An Epiphenomenon or a Clinically Important Entity? Sleep 2012;35:5-7.

11. Peker Y. REM sleep: A nightmare for patients with obstructive sleep apnea? Am J Respir Crit Care Med 2014;15;190:1088-90.

12. Izci B, Ardic S, Firat H, Sahin A, Altinors M, Karacan I. Reliability and validity studies of the Turkish version of the Epworth Sleepiness Scale. Sleep Breath 2008;12:161-8. 
13. Berry R, Brooks R, Gamaldo C, Harding S, Lloyd R, Marcus C. The AASM Manual for the Scoring of Sleep and Associated Events: Rules, Terminology and Technical Specifications, Version 2.3. www. aasmnet.org. Darien, Illinois. Am Acad Sleep Med 2016.

14. Conwell W, Patel B, Doeing D, Pamidi S, Knutson KL, Ghods F, Mokhlesi B. Prevalence, clinical features, and CPAP adherence in REM-related sleep-disordered breathing: A cross-sectional analysis of a large clinical population. Sleep Breath 2012;16:519-26.

15. Haba-Rubio J, Janssens JP, Rochat T, Sforza E. Rapid eye movementrelated disordered breathing: Clinical and polysomnographic features. Chest 2005;128:3350-7.

16. Chami HA, Baldwin CM, Silverman A, Zhang Y, Rapoport D, Punjabi NM, Gottlieb DJ. Sleepiness, quality of life, and sleep maintenance in REM versus non-REM sleep-disordered breathing. Am J Respir Crit Care Med 2010;181:997-1002.

17. Punjabi NM, Bandeen-Roche K, Marx JJ, Neubauer DN, Smith PL, Schwartz AR. The Association Between Daytime Sleepiness and Sleep-Disordered Breathing in NREM and REM Sleep. Sleep 2002;25:307-14.

18. Mazzotti DR, Keenan BT, Lim DC, Gottlieb DJ, Kim J, Pack Al. Symptom Subtypes of Obstructive Sleep Apnea Predict Incidence of Cardiovascular Outcomes. Am J Respir Crit Care Med 2019;200:493-506.

19. Jaussent I, Morin CM, Ivers H, Dauvilliers Y. Incidence, worsening and risk factors of daytime sleepiness in a population-based 5-year longitudinal study. Sci Rep 2017;7:1372.

20. Shao C, Jiang JB, Wu HC, Wu SB, Yu BY, Tang YD. Clinical assessment and polysomnographic study of sleep apnea in a Chinese population of snorers. J Zhejiang Univ Sci B 2015;16:215-23.

21. Shao C, Qi H, Lang R, Yu B, Tang Y, Zhang L, Wang X, Wang L. Clinical Features and Contributing Factors of Excessive Daytime Sleepiness in Chinese Obstructive Sleep Apnea Patients: The Role of Comorbid Symptoms and Polysomnographic Variables. Can Respir J 2019;2019:5476372.

22. Kushida CA, Littner MR, Hirshkowitz M, Morgenthaler TI, Alessi CA, Bailey D, Boehlecke B, Brown TM, Coleman J Jr, Friedman L, Kapen S, Kapur VK, Kramer M, Lee-Chiong T, Owens J, Pancer JP, Swick T], Wise MS; American Academy of Sleep Medicine. Practice parameters for the use of continuous and bilevel positive airway pressure devices to treat adult patients with sleep-related breathing disorders. Sleep 2006;29:375-80.

23. Oksenberg A, Arons E, Nasser K, Vander T, Radwan H. REM-related obstructive sleep apnea: The effect of body position. J Clin Sleep Med 2010;6:343-8.

24. Köseoglu Inönü H, Kanbay A, Demir O. A Different Clinical Type of OSAS: REM-Related OSAS. Eurasian J Pulmonol 2015;17:92-7.

25. Khan A, Harrison SL, Kezirian EJ, Ancoli-Israel S, O'Hearn D, Orwoll E, Redline S, Ensrud K, Stone KL; Osteoporotic Fractures in Men (MrOS) Study Research Group. Obstructive sleep apnea during rapid eye movement sleep, daytime sleepiness, and quality of life in older men in osteoporotic fractures in men (MrOS) sleep study. J Clin Sleep Med 2013;9:191-8.

26. Jennum P, Tønnesen P, Ibsen R, Kjellberg J. Obstructive sleep apnea: effect of comorbidities and positive airway pressure on all-cause mortality. Sleep Med 2017;36:62-6.

27. Weaver TE, Grunstein RR. Adherence to continuous positive airway pressure therapy: The challenge to effective treatment. Proc Am Thorac Soc 2008; 5:173-8.

28. Westlake K, Dostalova V, Plihalova A, Pretl M, Polak J. The Clinical Impact of Systematic Screening for Obstructive Sleep Apnea in a Type 2 Diabetes Population-Adherence to the Screening-Diagnostic Process and the Acceptance and Adherence to the CPAP Therapy Compared to Regular Sleep Clinic Patients. Front Endocrinol (Lausanne) 2018;29:714.

29. Rezaie L, Phillips D, Khazaie H. Barriers to acceptance and adherence to continuous positive airway pressure therapy in patients with obstructive sleep apnea: A report from Kermanshah Province, Western Iran. Patient Prefer Adherence 2018;1299-304.

30. Lee CHK, Leow LC, Song PR, Li H, Ong TH. Acceptance and adherence to continuous positive airway pressure therapy in patients with obstructive sleep apnea (OSA) in a southeast asian privately funded healthcare system. Sleep Sci 2017;10:57-63.

31. Sunwoo BY, Light M, Malhotra A. Strategies to augment adherence in the management of sleep-disordered breathing. Respirology 2020;25:363-71. 